\title{
Metode Belajar Tuntas dalam Meningkatkan Prestasi Belajar Mengarang Bahasa Indonesia pada Siswa Sekolah Dasar
}

\author{
Ismawati $^{1 凶}$ \\ ${ }^{1}$ SD Negeri 03 Kota Mukomuko, Kab. Mukomuko Bengkulu \\ 1ismawati.a.ma@gmail.com
}

\begin{abstract}
Composing is a skill to describe imagination in written or oral form. The problem that occurs in class is students having difficulty communicating their imagination in the form of writing or writing. Seen from the ability to make sentences that are still not related between one stanza with another. Therefore the purpose of this study is to find out the improvement of Indonesian learning achievement in the composing section after the implementation of Completed Learning, and determine the effect of motivation to learn Indonesian after applying the Completed Learning method. The research method used was a class action research method of three cycles. Each cycle consists of four stages: design, activity and observation, reflection, and revision. The data obtained in the form of formative test results, observation sheets of teaching and learning activities. Student achievement has increased from cycle I to III From the results of analysts it was found that 3 cycles namely, cycle I (65.22\%), cycle II (82.6\%), cycle III (91.13\%). The conclusion of this research is the Completed Learning teaching method through joint reading activities can have a positive effect on the motivation of students in $5^{\text {th }}$ grade of Public Elementary School 03 Mukomuko City and this learning model can be used as an alternative learning Indonesianumum.
\end{abstract}

Keywords: composing; classroom action research; learning outcomes

Abstrak : Mengarang merupakan keterampilan mendeskripsikan imajinasi dalam bentuk tulisan ataupun lisan. Masalah yang terjadi di kelas adalah siswa kesulitan untuk mengkomunikasikan imajinasinya baik berupa tulisan maupun tulisan. Terlihat dari kemampuan membuat kalimat yang masih tidak terkait antara satu bait dengan yang lainnya. Oleh karena itu tujuan dari penelitian ini adalah untuk mengetahui peningkatan prestasi belajar bahasa Indonesia pada bagian mengarang setelah diterapkannya Belajar Tuntas dan mengetahui pengaruh motivasi belajar bahasa Indonesia setelah diterapkannya metode Belajar Tuntas. Metode penelitian yang digunakan adalah metode penelitian tindakan kelas sebanyak tiga siklus. Setiap siklus terdiri atas empat tahap, yaitu rancangan, kegiatan dan pengamatan, refleksi, dan revisi. Data yang diperoleh berupa hasil tes formatif, lembar

Sitasi Jurnal:

Ismawati, I. (2020). Pendekatan Metode Belajar Tuntas Dalam Meningkatkan Prestasi Belajar Mengarang Bahasa Indonesia Pada Siswa Kelas V SDN.03 Kota Mukomuko Tahun Pelajaran 2018/2019. Disastra: Jurnal Pendidikan Bahasa dan Sastra Indonesia, 2(1), 8695.doi:http://dx.doi.org/10.29300/disastra.v2i1.2955 
observasi kegiatan belajar mengajar. prestasi belajar siswa mengalami peningkatan dari siklus I sampai III Dari hasil analis didapatkan bahwa 3 siklus yaitu, siklus I (65,22\%), siklus II (82,6\%), siklus III (91,13\%). Simpulan dari penelitian ini adalah metode pengajaran Belajar Tuntas melalui kegiatan membaca bersama dapat berpengaruh positif terhadap motivasi belajar siswa kelas V SDN 03 Kota Mukomuko serta model pembelajaran ini dapat digunakan sebagai salah satu alternatif pembelajaran bahasa Indonesia.

Kata Kunci : mengarang; penelitian tindakan kelas; hasil belajar.

\section{Pendahuluan}

Untuk melatih imajinasi siswa dan mengkomunikasikannya kembali baik dalam bentuk lisan maupun tulisan merupakan tujuan dari pembelajaran mengarang (Fathurrahman, 2018; Nugraha, MS, \& Fuad, 2019; Salbiah, 2019). Pembelajaran mengarang merupakan materi yang krusial karena bisa mengembangkan daya imajinasi siswa. Mengarang bisa dilakukan jika sudah menyimak apa yang menjadi imajinasi siswa (Agustina \& Oktavia, 2019). Kemudian mengkomunikasikannya kembali dalam bahasa tulisan maupun lisan. Hanya saja dalam prapenelitian yang dilakukan dalam penelitian ini hasil belajar siswa masih tidak mencukupi KKM. Dalam pengajaran bahasa Indonesia, ada tiga aspek yang perlu diperhatikan, yaitu aspek kognitif, aspek afektif, dan aspek psikomotor. Ketiga aspek itu berturut-turut menyangkut ilmu pengetahuan, perasaan, dan keterampilan atau kegiatan berbahasa. Ketiga aspek tersebut harus berimbang agar tujuan pengajaran bahasa yang sebenarnya dapat dicapai. Apabila pengajaran bahasa terlalu banyak mengotak-atik segi gramatikal saja (teori), siswa akan tahu tentang aturan bahasa, tetapi belum tentu dapat menerapkannya dalam tuturan maupun tulisan dengan baik.

Bahasa Indonesia erat kaitannya dengan guru bahasa Indonesia, yakni orangorang yang tugasnya setiap hari membina pelajaran bahasa Indonesia. Guru bahasa Indonesia merupakan orang yang merasa bertanggung jawab akan perkembangan bahasa Indonesia. Guru bahasa Indonesia juga akan selalu dituding oleh masyarakat bila hasil pengajaran bahasa Indonesia di sekolah tidak memuaskan. Berhasil atau tidaknya pengajaran bahasa Indonesia memang diantaranya ditentukan oleh faktor guru. Selain itu, faktor-faktor lainya seperti faktor siswa, metode pembelajaran, kurikulum (termasuk silabus), bahan pengajaran dan buku, serta yang tidak kalah pentingnya ialah perpustakaan sekolah dengan disertai pengelolaan yang memadai.

Saat ini pembelajaran bahasa Indonesia di sekolah-sekolah, yang dimulai dari taman kanak-kanak sampai SMA, bahkan sampai perguruan tinggi menuntut sumber daya manusianya untuk mampu memiliki imajinasi tinggi dan mengkomunikasikannya kembali dengan baik berdasarkan prinsip dalam kurikulum 2013 (Adang, 2012; Akhmad Yazidi, 2014; Alawiyah, 2015; Friska Fitriani Sholekah, 2020; Riwan Putri Bintari, Sudiana, \& Bagus Putrayasa, 2014). Mulyono Sumardi, Ketua Himpunan Pembina Bahasa Indonesia menyatakan bahwa, "Dalam dunia Pendidikan, keterampilan berbahasa Indonesia perlu mendapatkan tekanan yang lebih banyak lagi, mengingat kemampuan berbahasa Indonesia di kalangan pelajar ini juga disebabkan oleh kualitas guru, dari pihak lain munculnya anggapan bahwa setiap orang Indonesia pasti bisa berbahasa Indonesia. Anggapan ini justru ikut merunyamkan dunia kebahasaan Indonesia itu sendiri (Badudu, 1983).

Pembelajaran mengarang sebenarnya sangat penting diberikan kepada siswa sebagai latihan menggunakan bahasa secara 
aktif. Selain itu, mengarang di dalamnya secara otomatis mencakup banyak unsur kebahasaan termasuk kosa kata dan keterampilan penggunaan bahasa itu sendiri dalam bentuk bahasa tulis. Akan tetapi, dalam hal ini guru bahasa Indonesia dihadapkan pada dua masalah yang sangat dilematis. Di satu sisi guru bahasa harus dapat menyelesaikan target kurikulum yang harus dicapai dalam kurun waktu yang telah ditentukan. Sementara di sisi lain porsi waktu yang disediakan untuk pelajaran mengarang relatif terbatas, padahal untuk pelajaran mengarang seharusnya dibutuhkan waktu yang cukup panjang, karena diperlukan latihan-latihan yang cukup untuk memberikan siswa dalam karangmengarang. Dari dua persoalan tersebut dibutuhkan kreatifitas guru untuk mengatur materi pelajaran mengarang dapat diberikan semaksimal mungkin dengan tidak mengesampingkan materi yang lain.

Sekolah kita pada umumnya agak mengabaikan pembelajaran mengarang. Ada beberapa faktor penyebabnya, yaitu (1) sistem ujian yang biasanya menjabarkan soal-soal yang sebagian besar bersifat teoretis, (2) kelas yang terlalu besar dengan jumlah siswa berkisar antara empat puluh sampai lima puluh orang.

Materi ujian yang teoretis dapat menimbulkan motivasi guru bahasa Indonesia mengajarkan materi mengarang hanya untuk dapat menjawab soal-soal ujian. Sementara itu, aspek keterampilan diabaikan. Sedangkan dengan kelas yang jumlah siswanya lebih banyak memiliki akibat, yaitu biasanya guru enggan memberikan pelajaran mengarang karena ia harus memeriksa karangan siswa-siswanya yang berjumlah mencapai empat puluh sampai lima puluh lembar, kadang hal itu masih harus berhadapan dengan tulisantulisan siswa yang sulit dibaca. Belum lagi harus mengajar lebih dari satu kelas atau mengajar di sekolah lain, berarti yang harus diperiksa empat puluh kali sekian lembar karangan. Oleh karena itu, tidak jarang guru yang menyuruh siswanya mengarang hanya sebulan sekali atau bahkan sampai berbulanbulan.

Selain itu, ada asumsi sebagian guru yang menganggap tugas mengarang yang diberikan kepada siswa terlalu memberatkan atau tugas itu terlalu berat untuk siswa, sehingga guru merasa kasihan memberikan beban berat tersebut kepada siswanya. Guru terlalu pesimis dengan kemampuan siswanya. Asumsi tersebut tidak bisa dibenarkan, karena justru dengan seringnya latihan-latihan yang diberikan akan membuat siswa terbiasa dengan hal itu. Keterampilan berbahasa akan dapat dicapai dengan baik apabila dibiasakan. Apabila guru selalu dihantui oleh perasaan ini dan itu, bagaimana siswanya akan terbiasa menggunakan bahasa dengan sebaikbaiknya.

Penelitian sebelumnya yang dilakukan oleh Kartini (2016) menerapkan metode pembelajaran dengan menggunakan media komik sebagai sarana untuk meningkatkan hasil belajar mengarang memang cukup efektif. Akan tetapi penelitian tersebut hanya mendampingkan media saja, tidak penerapan metode pembelajaran.Penelitian yang dilakukan oleh Yasmin \& Erni (2017) hanya meminta siswa untuk berimajinasi saja, tidak sintaksis dalam metode pembelajaran tersebut. Penelitian ini bertujuan untuk mengetahui peningkatan prestasi belajar siswa setelah diterapkannya metode Belajar Tuntas pada siswa kelas V SDN.03 Kota Mukomuko

\section{Metode Penelitian}

Penelitian ini merupakan penelitian tindakan (action research) karena penelitian tindakan dilakukan untuk memecahkan masalah pembelajaran di kelas. Penelitian ini guru sering menggunakannya karena guru lebih menguasai kelas. Pendekatan yang digunakan adalah deskriptif kuantitatif, karena mendeskripsikan suatu metode pembelajaran diterapkan dan bagaimana 
hasil yang diinginkan dapat dicapai. Penelitian ini bertempat di SDN 03 Kota Mukomuko. Sekolah ini dipilih karena permasalahan yang ditemukan terjadi di sekolah ini. Peneliti juga merupakan guru kelas di sekolah ini.

Waktu penelitian berlangsung pada bulan Oktober semester ganjil tahun ajaran 2018/2019. Subjek penelitian adalah siswasiswi Kelas 5 SDN 03 Kota Mukomuko yang merupakan sampel penelitian. Sedangkan objek penelitiannya adalah peningkatan prestasi belajar siswanya pada materi pokok bahasan mengarang.

Penelitian tindakan kelas adalah suatu bentuk kajian yang bersifat reflektif oleh pelaku tindakan yang dilakukan untuk meningkatkan kemantapan rasional dari tindakan mereka dalam melaksanakan tugas, memperdalam pemahaman terhadap tindakan-tindakan yang dilakukan itu, serta memperbaiki kondisi dimana praktik pembelajaran tersebut dilakukan (Alidawati, 2019; Dewi, 2016; Harmaini, 2019)

Sesuai dengan jenis penelitian yang dipilih, yaitu penelitian tindakan, maka penelitian ini menggunakan model penelitian tindakan Kemmis, McTaggart, \& Nixon (2013) yaitu berbentuk spiral dari sklus yang satu ke siklus yang berikutnya. Setiap siklus meliputi planning (rencana), action (tindakan), observation (pengamatan), dan reflection (refleksi). Langkah pada siklus berikutnya adalah perencanaan yang sudah direvisi, tindakan, pengamatan, dan refleksi. Sebelum masuk pada siklus 1 dilakukan tindakan pendahuluan yang berupa identifikasi permasalahan. Siklus spiral dari tahap-tahap penelitian tindakan kelas dapat dilihat pada gambar 1.

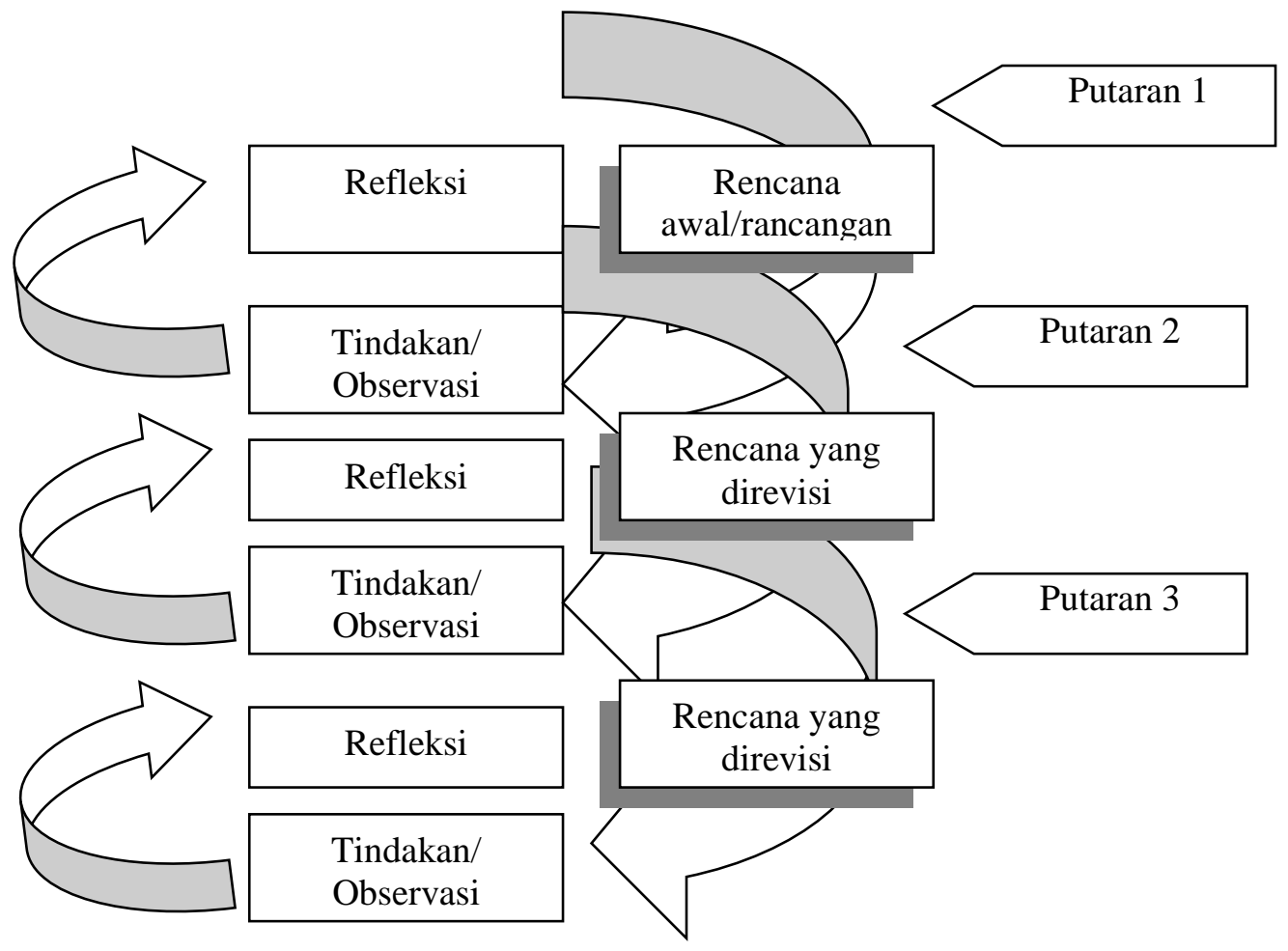

Gambar 1. Alur Penelitian Tindakan Kelas 
Rancangan atau rencana awal, sebelum mengadakan penelitian peneliti menyusun rumusan masalah, tujuan dan membuat rencana tindakan, termasuk di dalamnya instrumen penelitian dan perangkat pembelajaran.

Kegiatan dan pengamatan, meliputi tindakan yang dilakukan oleh peneliti sebagai upaya membangun pemahaman konsep siswa serta mengamati hasil atau dampak dari diterapkannya metode pembelajaran model Belajar Tuntas.

Refleksi, peneliti mengkaji, melihat, dan mempertimbangkan hasil atau dampak dari tindakan yang dilakukan berdasarkan lembar pengamatan yang diisi oleh pengamat.

Rancangan/rencana yang direvisi, berdasarkan hasil refleksi dari pengamat membuat rancangan yang direvisi untuk dilaksanakan pada siklus berikutnya.

Observasi dibagi dalam tiga putaran, yaitu putaran 1, 2 dan 3. Masing-masing putaran dikenai perlakuan yang sama (alur kegiatan yang sama) dan membahas satu sub pokok bahasan yang diakhiri dengan tes formatif di akhir masing putaran. Dibuat dalam tiga putaran dimaksudkan untuk memperbaiki sistem pengajaran yang telah dilaksanakan.

Instrumen penelitian yang digunakan dalam penelitian ini adalah 1) silabus, yaitu seperangkat rencana dan pengaturan tentang kegiatan pembelajaran pengelolahan kelas, serta penilaian hasil belajar. 2) Rencana Pembelajaran (RP), yaitu merupakan perangkat pembelajaran yang digunakan sebagai pedoman guru dalam mengajar dan disusun untuk tiap putaran. Masing-masing RP berisi kompetensi dasar, indikator pencapaian hasil belajar, tujuan pembelajaran khusus, dan kegiatan belajar mengajar.3). Tes formatif yang disusun berdasarkan tujuan pembelajaran yang dicapai, digunakan untuk mengukur kemampuan penulisan karangan dalam Bahasa Indonesia. Tes formatif dibuat berdasarkan tema dengan berbagai pilihan, sehingga siswa bisa memilih tema yang sesuai dengan imajinasinya dan mengkomunikasikannya dalam bentuk tulisan

Untuk mempermudah evaluasi terhadap tingkat kemampuan siswa, perlu dirumuskan kriteria penilaian sebagai berikut:

1. Kategori benar semua. (memiliki kalimat efektif, memiliki kalimat majemuk, dan memiliki keterkaitan antar bait)

2. Kategori benar sebagian. memiliki kalimat efektif, memiliki kalimat majemuk)

3. Kategori salah semua.

4. Kategeri tanpa percakapan.

Persentase dan jumlah kategori 1 dan 2 menunjukkan tingkat keberhasilan pembelajaran. Kriteria ini diberikan karena pertimbangan bahwa penulisan kalimat langsung merupakan pekerjaan yang sulit dicapai kesempurnaannya.

Untuk ketuntasan belajar ada dua kategori ketuntasan belajar yaitu secara perorangan dan secara klasikal. Berdasarkan petunjuk pelaksanaan belajar mengajar kurikulum 2013, yaitu seorang siswa telah tuntas belajar bila telah mencapai skor $65 \%$ atau nilai 65 , dan kelas disebut tuntas belajar bila di kelas tersebut terdapat $85 \%$ yang telah mencapai daya serap lebih dari atau sama dengan 65\%. Untuk menghitung persentase ketuntasan belajar digunakan rumus sebagai berikut:

$$
P=\frac{\sum \text { Siswa.yang.tuntas.belajar }}{\sum \text { Siswa }} \times 100 \%
$$

\section{Hasil dan Pembahasan}

\section{Siklus I}

a. Tahap Perencanaan

Pada tahap ini peneliti mempersiapkan perangkat pembelajaran yang terdiri dari rencana pelajaran 1 , soal tes formatif 1 dan alat-alat pengajaran yang mendukung. Selain itu juga dipersiapkan lembar 
observasi pengolahan belajar aktif. Metode belajar tuntas di tuangkan dalam RPP agar lebih terarah pembelajarannya.

b. Tahap Kegiatan dan Pelaksanaan

Pelaksanaan kegiatan belajar mengajar untuk siklus I dilaksanakan pada tanggal 3 Oktober 2018 di Kelas V dengan jumlah siswa 23 siswa. Dalam hal ini peneliti bertindak sebagai guru. Adapun proses belajar mengajar mengacu pada rencana pelajaran yang telah dipersiapkan.

Pengamatan (observasi) dilaksanakan bersamaan dengan pelaksaaan belajar mengajar. Sebagai pengamat ataupun observer adalah wali Kelas V

Pada akhir proses belajar mengajar siswa diberi tes formatif I dengan tujuan untuk mengetahui tingkat keberhasilan siswa dalam proses belajar mengajar yang telah dilakukan. Adapun data hasil penelitian pada siklus I dapat dilihat pada tabel 1.

Tabel 1. Hasil Kegiatan Belajar Mengajar Mengarang Siklus I

\begin{tabular}{|c|c|c|c|c|c|}
\hline \multirow{2}{*}{ No. } & \multirow{2}{*}{$\begin{array}{l}\text { Nama } \\
\text { Siswa }\end{array}$} & \multicolumn{4}{|c|}{ Jenis Kesalahan } \\
\hline & & 1 & 2 & 3 & 4 \\
\hline 1 & Aulia & $\sqrt{ }$ & & & \\
\hline 2 & Bayu & & & & $\sqrt{ }$ \\
\hline 3 & Ani & & $\sqrt{ }$ & & \\
\hline 4 & Rani & & & $\sqrt{ }$ & \\
\hline 5 & Rima & & $\sqrt{ }$ & & \\
\hline 6 & Deni & $\sqrt{ }$ & & & \\
\hline 7 & Nana & & $\sqrt{ }$ & & \\
\hline 8 & Ozil & & & $\sqrt{ }$ & \\
\hline 9 & Diva & $\sqrt{ }$ & & & \\
\hline 10 & Aksa & & & & $\sqrt{ }$ \\
\hline 11 & Dika & $\sqrt{ }$ & & & \\
\hline 12 & Fika & & $\sqrt{ }$ & & \\
\hline 13 & Rafa & & $\sqrt{ }$ & & \\
\hline 14 & Dila & $\sqrt{ }$ & & & \\
\hline 15 & Ari & $\sqrt{ }$ & & & \\
\hline 16 & Santa & & $\sqrt{ }$ & & \\
\hline 17 & Akbar & & & & $\sqrt{ }$ \\
\hline 18 & Bima & & & $\sqrt{ }$ & \\
\hline 19 & Reni & $\sqrt{ }$ & & & \\
\hline 20 & Fadil & $\sqrt{ }$ & & & \\
\hline 21 & Eka & & & & $\sqrt{ }$ \\
\hline 22 & Sinta & $\sqrt{ }$ & & & \\
\hline 23 & Ayu & & & $\sqrt{ }$ & \\
\hline & umlah & 9 & 6 & 4 & 4 \\
\hline
\end{tabular}

Keterangan:
1. Benar semua
2. Benar sebagian
: 9 orang
3. Salah semua
4. Tanpa percakapan
: 6 orang
: 4 orang
: 4 orang
Klasikal
: Belum tuntas

Tabel 2. Hasil Tes Formatif Siswa pada Siklus I

\begin{tabular}{|l|l|l|}
\hline No & \multicolumn{1}{|c|}{ Uraian } & $\begin{array}{c}\text { Hasil } \\
\text { Silkus I }\end{array}$ \\
\hline 1 & Benar semua & $39,13 \%$ \\
2 & Benar sebagian & $26,09 \%$ \\
3 & Salah semua & $17,39 \%$ \\
4 & Tanpa percakapan & $17,39 \%$ \\
\hline
\end{tabular}

Tingkat keberhasilan pada siklus I adalah $39,13 \%+26,09 \%=65,22 \%$. Siswa yang membuat karangan tanpa percakapan sebanyak 4 siswa dan yang membuat karangan dengan percakapan tapi salah cara membuat kutipannya sebanyak 4 orang. Hal ini menunjukkan siswa kurang memahami penjelasan guru. Hasil observasi masih kurang memuaskan, karena perhatian siswa diperoleh secara paksa yaitu melalui diberikan tindakan verbal yang tegas. Meskipun hanya tahap awal. Perhatian tidak tumbuh secara alamiah.

Hasil tersebut menunjukkan bahwa pada siklus pertama secara klasikal siswa belum tuntas belajar, karena siswa yang memahami mata pelajaran mengarang hanya sebesar 65,22\% lebih kecil dari persentase ketuntasan yang dikehendaki yaitu sebesar $85 \%$. Hal ini disebabkan karena siswa masih merasa baru dan belum mengerti apa yang dimaksudkan dan digunakan guru dengan menerapkan model belajar aktif.

\section{c. Refleksi}

Dalam pelaksanaan kegiatan belajar mengajar diperoleh informasi dari hasil pengamatan (lembar observer) yang ditulis oleh observer (pengamat) dapat disimpulkan sebagai berikut:

1. Guru kurang baik dalam memotivasi siswa dan dalam menyampaikan tujuan pembelajaran 
2. guru kurang baik dalam pengelolaan waktu

3. Siswa kurang bitu antusias selama pembelajaran

\section{d. Revisi} berlangsung

Pelaksanaan kegiatan belajar mengajar pada siklus I ini masih terdapat kekurangan, sehingga perlu adanya revisi untuk dilakukan pada siklus berikutnya.

1. Guru perlu lebih terampil dalam memotivasi siswa dan lebih jelas dalam menyampaikan tujuan pembelajaran. Dimana siswa diajak untuk terlibat langsung dalam setiap kegiatan yang akan dilakukan.

2. Guru perlu mendistribusikan waktu secara baik dengan menambahkan informasiinformasi yang dirasa perlu dan memberi catatan

3. Guru harus lebih terampil dan bersemangat dalam memotivasi siswa sehingga siswa bisa lebih antusias.

\section{Siklus II}

a. Tahap perencanaan

Pada tahap inipeneliti mempersiapkan perangkat pembelajaran yang terdiri dari rencana pelajaran 2, soal tes formatif II dan alat-alat pengajaran yang mendukung. Selain itu juga dipersiapkan lembar observasi pengelolaan belajar aktif dan lembar observasi guru dan siswa.

b. Tahap kegiatan dan pelaksanaan

Pelaksanaan kegiatan belajar mengajar untuk siklus II dilaksanakan pada tanggal 10 Oktober 2018 di Kelas 5 dengan jumlah siswa 23 siswa. Dalam hal ini peneliti bertindak sebagai guru. Adapun proses belajar mengajar mengacu pada rencana pelajaran dengan memperhatikan revisi pada siklus I, sehingga kesalahan atau kekurangan pada siklus I tidak terulang lagi pada siklus II.
Pengamatan ataupun observasi oleh observer dilaksanakan bersamaan dengan pelaksanaan belajar mengajar. Sebagai pengamat adalah wali Kelas V SDN.03 Kota Mukomuko

Pada akhir proses belajar mengajar siswa diberi tes formatif II dengan tujuan untuk mengetahui tingkat keberhasilan siswa dalam proses belajar mengajar yang telah dilakukan. Instrumen yang digunakan adalah tes formatif II. Hasil belajar ini didapatkan dari tes hasil belajar siswa pada pembelajaran mengarang yang dilaksanakan pada akhir siklus II. Dari pantauan observer, pada akhir siklus II siswa memberikan usaha terbaiknya agar mendapatkan nilai maksimal. Adapun data hasil penelitian pada siklus II terlihat pada tabel 3 .

\section{Tabel 3. Hasil Kegiatan Belajar Mengajar Mengarang Siklus II}

\begin{tabular}{|c|l|c|c|c|c|}
\hline \multirow{2}{*}{ No. } & \multirow{2}{*}{ Nama } & \multicolumn{5}{|c|}{ Jenis Kesalahan } \\
\hline & Siswa & 1 & 2 & 3 & 4 \\
\hline 1 & Aulia & $\sqrt{ }$ & & & \\
\hline 2 & Bayu & & & & $\sqrt{ }$ \\
\hline 3 & Ani & & $\sqrt{ }$ & & \\
\hline 4 & Rani & & $\sqrt{ }$ & & \\
\hline 5 & Rima & & $\sqrt{ }$ & & \\
\hline 6 & Deni & $\sqrt{ }$ & & & \\
\hline 7 & Nana & & $\sqrt{ }$ & & \\
\hline 8 & Ozil & & & $\sqrt{ }$ & \\
\hline 9 & Diva & $\sqrt{ }$ & & & \\
\hline 10 & Aksa & $\sqrt{ }$ & & & \\
\hline 11 & Dika & $\sqrt{ }$ & & & \\
\hline 12 & Fika & & $\sqrt{ }$ & & \\
\hline 13 & Rafa & & $\sqrt{ }$ & & \\
\hline 14 & Dila & $\sqrt{ }$ & & & \\
\hline 15 & Ari & $\sqrt{ }$ & & & \\
\hline 16 & Santa & & $\sqrt{ }$ & & \\
\hline 17 & Akbar & & & & $\sqrt{ }$ \\
\hline 18 & Bima & & & $\sqrt{ }$ & \\
\hline 19 & Reni & $\sqrt{ }$ & & & \\
\hline 20 & Fadil & $\sqrt{ }$ & & & \\
\hline 21 & Eka & & $\sqrt{ }$ & & \\
\hline 22 & Sinta & $\sqrt{ }$ & & & \\
\hline 23 & Ayu & & & $\sqrt{ }$ & \\
\hline Jumlah & 10 & 9 & 2 & 2 \\
\hline Keternyyyy
\end{tabular}

Keterangan:
1. Benar semua
: 10 orang
2. Benar sebagian
: 10 orang
3. Salah semua
: 2 orang 


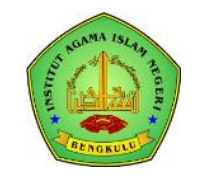

$\begin{array}{ll}\text { 4. Tanpa percakapan } & : 1 \text { orang } \\ \text { Klasikal } & : \text { Belum tuntas }\end{array}$

Tabel 4. Hasil Tes Formatif Siswa pada Siklus II

\begin{tabular}{|c|l|c|}
\hline No & \multicolumn{1}{|c|}{ Uraian } & $\begin{array}{c}\text { Hasil } \\
\text { Silkus II }\end{array}$ \\
\hline 1 & Benar semua & $43,47 \%$ \\
2 & Benar sebagian & $39,13 \%$ \\
3 & Salah semua & $8,7 \%$ \\
4 & Tanpa percakapan & $8,7 \%$ \\
\hline
\end{tabular}

Tingkat keberhasilan pada siklus II adalah $43,47 \%+39,13 \%=82,6 \%$. Siswa yang membuat karangan tanpa percakapan sebanyak 2 siswa dan yang membuat karangan dengan percakapan tapi salah cara membuat kutipannya sebanyak 2 orang. Hasil ini menunjukkan bahwa ketuntasan belajar mencapai $82,6 \%$ atau ada 23 siswa yang tuntas belajar. Hasil ini menunjukkan bahwa pada siklus II ini ketuntasan belajar secara klasikal telah mengalami peningkatan sedikit lebih baik dari siklus I. Adanya peningkatan hasil belajar siswa ini karena setelah guru menginformasikan bahwa setiap akhir pelajaran akan selalu diadakan tes sehingga pada pertemuan berikutnya siswa lebih termotivasi untuk belajar. Selain itu siswa juga sudah mulai mengerti apa yang dimaksudkan dan dinginkan guru dengan menerapkan model belajar aktif.

c. Refleksi

Dalam pelaksanaan kegiatan belajar diperoleh informasi dari hasil pengamatan sebagai berikut:

1. Memotivasi siswa

2. Membimbing siswa merumuskan kesimpulan/menemukan konsep

3. Pengelolaan waktu

d. Revisi Rancangan

Pelaksanaan kegiatan belajar pada siklus II ini masih terdapat kekurangan-kekurangan. Maka perlu adanya revisi untuk dilaksanakan pada siklus II antara lain:

1) Guru dalam memotivasi siswa hendaknya dapat membuat siswa
Volume 2, Nomor 1, Januari 2020

ISSN 2655-3031 (P), 2655-7851 (O)

lebih termotivasi selama proses belajar mengajar berlangsung.

2) Guru harus lebih dekat dengan siswa sehingga tidak ada perasaan takut dalam diri siswa baik untuk mengemukakan pendapat atau bertanya.

3) Guru harus lebih sabar dalam membimbing siswa merumuskan kesimpulan/menemukan konsep.

4) Guru harus mendistribusikan waktu secara baik sehingga kegiatan pembelajaran dapat berjalan sesuai dengan yang diharapkan.

5)Guru sebaiknya menambah lebih banyak contoh soal dan memberi soal-soal latihan pda siswa untuk dikerjakan pada setiap kegiatan belajar mengajar.

\section{Siklus III}

a. Tahap Perencanaan

Pada tahap ini peneliti mempersiapkan perangkat pembelajaran yang terdiri dari rencana pelajaran 3, soal tes formatif 3 dan alat-alat pengajaran yang mendukung. Selain itu juga dipersiapkan lembar observasi pengelolaan cara belajar aktif model penajaran terarah dan lembar observasi aktivitas guru dan siswa.

b. Tahap kegiatan dan pengamatan

Pelaksanaan kegiatan belajar mengajar untuk siklus III dilaksanakan pada tanggal 17 Oktober 2018 di Kelas V dengan jumlah siswa 23 siswa. Dalam hal ini peneliti bertindak sebagai guru. Adapun proses belajar mengajar mengacu pada rencana pelajaran dengan memperhatikan revisi pada siklus II, sehingga kesalahan atau kekurangan pada siklus II tidak terulang lagi pada siklus III.

Pengamatan dilaksanakan bersamaan dengan pelaksanaan belajar mengajar. Sebagai pengamat adalah wali Kelas V SDN.03 Kota Mukomuko dan seorang sukarelawan yang merupakan teman sejawat peneliti sebagai guru. 
Pada akhir proses belajar mengajar siswa diberi tes formatif III dengan tujuan untuk mengetahui tingkat keberhasilan siswa dalam proses belajar mengajar yang telah dilakukan. Instrumen yang digunakan adalah tes formatif III. Adapun data hasil penelitian pada hasil belajar pada siklus III tertulis pada tabel 5 .

Tabel 5. Hasil Kegiatan Belajar Mengarar Mengarang Siklus III

\begin{tabular}{|c|l|c|c|c|c|}
\hline \multirow{2}{*}{ No. } & \multirow{2}{*}{ Nama } & \multicolumn{5}{|c|}{ Jenis Kesalahan } \\
\hline & Siswa & 1 & 2 & 3 & 4 \\
\hline 1 & Aulia & $\sqrt{ }$ & & & \\
\hline 2 & Bayu & & & $\sqrt{ }$ & \\
\hline 3 & Ani & & $\sqrt{ }$ & & \\
\hline 4 & Rani & & $\sqrt{ }$ & & \\
\hline 5 & Rima & & $\sqrt{ }$ & & \\
\hline 6 & Deni & $\sqrt{ }$ & & & \\
\hline 7 & Nana & & $\sqrt{ }$ & & \\
\hline 8 & Ozil & & $\sqrt{ }$ & & \\
\hline 9 & Diva & $\sqrt{ }$ & & & \\
\hline 10 & Aksa & $\sqrt{ }$ & & & \\
\hline 11 & Dika & $\sqrt{ }$ & & & \\
\hline 12 & Fika & & $\sqrt{ }$ & & \\
\hline 13 & Rafa & & $\sqrt{ }$ & & \\
\hline 14 & Dila & $\sqrt{ }$ & & & \\
\hline 15 & Ari & $\sqrt{ }$ & & & \\
\hline 16 & Santa & $\sqrt{ }$ & $\sqrt{ }$ & & \\
\hline 17 & Akbar & & & $\sqrt{ }$ & \\
\hline 18 & Bima & & & & \\
\hline 19 & Reni & $\sqrt{ }$ & & & \\
\hline 20 & Fadil & $\sqrt{ }$ & & & \\
\hline 21 & Eka & & $\sqrt{ }$ & & \\
\hline 22 & Sinta & $\sqrt{ }$ & & & \\
\hline 23 & Ayu & $\sqrt{ }$ & & & \\
\hline & Jumlah & 12 & 9 & 2 & - \\
\hline
\end{tabular}

Keterangan:

1. Benar semua

: 12 orang

2. Benar sebagian

: 9 orang

3. Salah semua

: 2 orang

4. Tanpa percakapan :-

Klasikal

: Tuntas
Tabel 6. Hasil Tes Formatif Siswa pada Siklus III

\begin{tabular}{|c|l|c|}
\hline No & \multicolumn{1}{|c|}{ Uraian } & $\begin{array}{c}\text { Hasil } \\
\text { Silkus III }\end{array}$ \\
\hline 1 & Benar semua & $52,17 \%$ \\
2 & Benar sebagian & $39,13 \%$ \\
3 & Salah semua & $8,7 \%$ \\
4 & Tanpa percakapan & - \\
\hline
\end{tabular}

Tingkat keberhasilan pada siklus III adalah 52,17 \% +39,13\%=91,3\%. Siswa yang membuat karangan tanpa percakapan tidak ada dan yang membuat karangan dengan percakapan tapi salah cara membuat kutipannya sebanyak 2 orang. Hasil ini menunjukkan bahwa ketuntasan belajar mencapai 91,3\% (hampir sempurna) atau ada 23 siswa yang tuntas belajar. Hasil ini menunjukkan bahwa pada siklus III ini ketuntasan belajar secara klasikal telah tercapai. Adanya peningkatan hasil belajar pada siklus III ini dipengaruhi oleh adanya peningkatan kemampuan guru dalam menerapkan belajar tuntas sehingga siswa menjadi lebih terbiasa dengan pembelajaran seperti ini sehingga siswa lebih mudah dalam memahami materi yang telah diberikan oleh guru sebagai peneliti.

\section{c. Refleksi}

Pada tahap ini akah dikaji apa yang telah terlaksana dengan baik maupun yang masih kurang baik dalam proses belajar mengajar dengan penerapan belajar aktif. Dari data-data yang telah diperoleh dapat duraikan sebagai berikut:

1. Selama proses belajar mengajar guru telah melaksanakan semua pembelajaran dengan baik. Meskipun ada beberapa aspek yang belum sempurna, tetapi persentase pelaksanaannya untuk masing-masing aspek cukup besar.

2. Berdasarkan data hasil pengamatan diketahui bahwa siswa aktif selama proses belajar berlangsung. 
3. Kekurangan pada siklus-siklus sebelumnya sudah mengalami perbaikan dan peningkatan sehingga menjadi lebih baik.

4. Hasil belajar siswsa pada siklus III mencapai ketuntasan.

\section{d. Revisi Pelaksanaan}

Pada siklus III guru telah menerapkan belajar aktif dengan baik dan dilihat dari aktivitas siswa serta hasil belajar siswa pelaksanaan proses belajar mengajar sudah berjalan dengan baik. Maka tidak diperlukan revisi terlalu banyak, tetapi yang perlu diperhatikan untuk tindakan selanjutnya adalah memaksimalkan dan mepertahankan apa yang telah ada dengan tujuan agar pada pelaksanaan proses belajar mengajar selanjutnya penerapan belajar aktif dapat meningkatkan proses belajar mengajar sehingga tujuan pembelajaran dapat tercapai.

\section{Pembahasan}

1. Ketuntasan Hasil belajar Siswa Melalui hasil peneilitian ini menunjukkan bahwa cara belajar aktif model Belajar Tuntas memiliki dampak positif dalam meningkatkan prestasi belajar siswa. Hal ini dapat dilihat dari semakin mantapnya pemahaman siswa terhadap materi yang disampaikan guru (ketuntasan belajar meningkat dari sklus I, II, dan III) yaitu masing-masing $65,22 \%, 82,6 \%$, dan 91,3\%. Pada siklus III ketuntasan belajar siswa secara klasikal telah tercapai.

2. Kemampuan Guru dalam Mengelola Pembelajaran

Berdasarkan analisis data, diperoleh aktivitas siswa dalam proses belajar aktif dalam setiap siklus mengalami peningkatan. Hal ini berdampak positif terhadap prestasi belajar siswa yaitu dapat ditunjukkan dengan meningkatnya nilai rata-rata siswa pada setiap siklus yang terus mengalami peningkatan.

\section{Simpulan}

Kemampuan menuliskan kalimat langsung dalam karangan dapat ditingkatkan dengan cara belajar tuntas. Kalimat langsung memiliki sistem penulisan yang sangat rumit, oleh karena itu pembelajarannya perlu secara berulangulang . Pelajaran mengarang yang tujuan akhirnya adalah agar mengeskalasi imajinasi siswa dapat ditingkatkan oleh metode belajar tuntas.

Dari hasil kegiatan pembelajaran yang telah dilakukan selama tiga siklus, dan berdasarkan seluruh pembahasan serta analisis yang telah dilakukan

Pembelajaran dengan metode belajar tuntas memiliki dampak positif dalam meningkatkan prestasi belajar siswa yang ditandai dengan peningkatan ketuntasan belajar siswa dalam setiap siklus, yaitu siklus I $(68,18 \%)$, siklus II $(77,28 \%)$, siklus III $(86,35 \%)$. Penerapan cara belajar aktif model Belajar Tuntas mempunyai pengaruh positif, yaitu dapat meningkatkan motivasi belajar siswa yang ditunjukan dengan ratarata jawaban siswa yang menyatakan bahwa siswa tertarik dan berminat dengn model belajar aktif sehingga mereka menjadi termotivasi untuk belajar.

\section{Daftar Pustaka}

Adang, S. (2012). Kurikulum dan Pembelajaran. Bandung: Yayasan Kesuma Karya.

Agustina, T., \& Oktavia, W. (2019). ANALISIS KESALAHAN BERBAHASA PADA BAHAN AJAR KELAS MENYIMAK PROGRAM BIPA IAIN SURAKARTA. Disastra: Jurnal Pendidikan Bahasa Dan Sastra Indonesia, 1(2), 60. https://doi.org/10.29300/disastra.v1i2.1866

Akhmad Yazidi. (2014). MEMAHAMI MODEL-MODEL PEMBELAJARAN DALAM KURIKULUM 2013 (THE UNDERSTANDING OF MODEL OF TEACHING IN CURRICULUM 2013). JURNAL BAHASA, SATRA, DAN PEMBELAJARANNYA. 
Alawiyah, F. (2015). Kesiapan Guru dalam Implementasi Kurikulum 2013. Kajian Singkat.

Alidawati, A. (2019). Meningkatkan Hasil Belajar Siswa Dengan Menggunakan Media Gambar Berupa Rumah Adat Tentang Keragaman Budaya Di Indonesia Pada Pelajaran IPS Di Kelas V SD Negeri 03 Kota Mukomuko. Indonesian Journal of Social Science Education (IJSSE), 1(1), 78-84.

Badudu, Y. (1983). MASALAH PENGEMBANGAN BAHASA INDONESIA SEBAGAI BAHASA HUKUM. Jurnal Hukum \& Pembangunan. https://doi.org/10.21143/jhp.vol13.no3.968

Dewi, P. S. (2016). Perspektif Guru Sebagai Implementasi Pembelajaran Inkuiri Terbuka dan Inkuiri Terbimbing terhadap Sikap Ilmiah dalam Pembelajaran Sains. Tadris: Jurnal Keguruan Dan Ilmu Tarbiyah, 1(2), 179. https://doi.org/10.24042/tadris.v1i2.1066

Fathurrahman, F. (2018). PENINGKATAN PROFESIONALISME GURU BAHASA MELALUI SUPERVISI PENGAJARAN KEPALA SEKOLAH. JURNAL REFORMA.

https://doi.org/10.30736/rfma.v7i1.38

Friska Fitriani Sholekah. (2020). Pendidikan Karakter Dalam Kurikulum 2013. Childhood Education: Jurnal Pendidikan Anak Usia Dini.

Harmaini, H. (2019). PENINGKATKAN HASIL BELAJAR BAHASA INDONESIA MELALUI MODEL PEMBELAJARAN INTERAKTIF PADA SISWA KELAS III SDN 05 KABUPATEN MUKOMUKO. Disastra: Jurnal Pendidikan Bahasa Dan Sastra Indonesia, $\quad 1(1), \quad 60$. https://doi.org/10.29300/disastra.v1i1.1466

Kartini, K. (2016). Penggunaan Media Komik Untuk Meningkatkan Hasil Belajar Mengarang Pelajaran Bahasa Indonesia Kelas VI Pada Min Uteun Gathom. Lentera: Jurnal Ilmiah Sains Dan Teknologi.

Kemmis, S., McTaggart, R., \& Nixon, R.
Volume 2, Nomor 1, Januari 2020

ISSN 2655-3031 (P), 2655-7851 (O)

(2013). The Action Research Planner: Doing Critical Participatory Action Research. Berlin: Springer Science \& Business Media.

Nugraha, J., MS, Z., \& Fuad, N. (2019). PENINGKATAN KETERAMPILAN MENULIS DESKRIPSI MELALUI PENDEKATAN SAINTIFIK DENGAN METODE PROBLEM BASED LEARNING DI KELAS IV SEKOLAH DASAR. Prosiding Seminar Nasional Pendidikan KALUNI. https://doi.org/10.30998/prokaluni.v2i0.37

Riwan Putri Bintari, N. L. G., Sudiana, I. N., \& Bagus Putrayasa, I. (2014). Pembelajaran Bahasa Indonesia Berdasarkan Pendekatan Saintifik ( Problem Based Learning ) Sesuai Kurikulum 2013 Di Kelas Vii Smp Negeri 2 Amlapura. E- Journal Program Pascasarjana Universitas Pendidikan Ganesha.

Salbiah, A. (2019). PENERAPAN METODE PEMBELAJARAN IMAJINATIF DALAM MENINGKATKAN PRESTASI BELAJAR MENGARANG BAHASA INDONESIA. Jurnal Visi Ilmu Pendidikan.

https://doi.org/10.26418/jvip.v11i1.30041

Yasmin, F., \& Erni, E. (2017). METODE PEMBELAJARAN IMAJINATIF DALAM MENINGKATKAN HASIL BELAJAR MENGARANG BAHASA INDONESIA DENGAN MENGGUNAKAN MEDIA LAGU. 3(1), 238-245. 